\title{
INTEGRASI NILAI-NILAI KECERDASAN EMOSIONAL DALAM KURIKULUM PENDIDIKAN AGAMA ISLAM DI SMA: PERSPEKTIF DANIEL GOLEMAN
}

\author{
Ivan Riyadi \\ STAIN Syaikh Abdurrahman Siddik Bangka Belitung \\ E-mail: ivanriyadi91@gmail.com
}

\begin{abstract}
This articel was conducted based on the consideration that the current emotional intelligence is still indispensable in shaping the behavior of students. With specification on the subjects of Islamic education, this article tried to connect the emotional intelligence of high school students on Islamic Education. This article examines to determine how Islamic religious education policies that have been implemented in high school and to determine the relevance of emotional intelligence of high school students against the teachings of Islam. To get a complete this article. libarary research approach. Data was collected through literature study includes studying, studying and citing theories or concepts from a number of literature. Books, journals, magazines and others. It can be applied to educate children who are emotionally intelligent with the ability to recognize self-managing emotions productively utilize emotions, empathy, and the ability to build social relationships.
\end{abstract}

Abstrak. Artikel ini ditulis berdasarkan pertimbangan bahwa saat ini kecerdasan emosional sangat diperlukan dalam membentuk prilaku siswa. Dengan mengkhususkan pada mata pelajaran Pendidikan Agama Islam, tulisan ini mencoba merelevansikan kecerdasan emosional siswa SMA terhadap Pendidikan Agama Islam. Dengan harapan dapat mengarahkan kecerdasan emosional siswa SMA terhadap ajaran Islam. Untuk mendapatkan gambaran yang utuh dalam artikel ini, maka digunakan pendekatan Libarary research. Pengumpulan data dilakukan dengan: mempelajari, mendalami dan mengutip teori-teori atau konsep dari sejumlah literatur. Hal ini dapat diterapkan untuk mendidik anak yang cerdas secara emosional dengan kemampuan mengenali diri, mengelola emosi, memanfaatkan emosi secara produktif, empati, dan kesanggupan membina hubungan sosial.

Kata Kunci : Relevance, Emotional Intelligence, and Islamic education 


\section{PENDAHULUAN}

Manusia merupakan makhluk ciptaan Tuhan yang paling sempurna dan mulia di dunia ini, karena kesempurnaan itulah manusia dikaruniai berbagai potensi yang sangat luar biasa di antaranya adalah potensi kecerdasan. Menurut penelitian Daniel Goleman seorang psikolog dari Harvard menunjukkan bahwa manusia mempunyai suatu jenis potensi dasar yang lain, yaitu kecerdasan emosional. Menurut pendapatnya bahwa kecerdasanakan dapat secara efektif apabila seseorang mampu memfungsikan kecerdasan emosionalnya. ${ }^{1}$ Kecerdasan emosional (Emotional Quotient) $^{2}$ dapat dilatih, dipelajari dan dikembangkan pada masa kanak-kanak, sehingga masih ada peluang untuk menumbuhkembangkan dan meningkatkannya untuk memberikan sumbangan bagi sukses hidup seseorang. Sedangkan kecerdasan intelektual sendiri menurut Daniel Goleman tidak dapat banyak diubah oleh pengalaman dan pendidikan. Kecerdasan intelektual cenderung sebagai bawaan sehingga kita tidak dapat berbuat banyak untuk meningkatkannya.

${ }^{1}$ Daniel Goleman, Kecerdasan Emosi Untuk Mencapai Puncak Prestasi, Cet. IV (terj) alex Tri Kantjono Widodo (Jakarta: Gramedia Puskta Utama 2001), h. 18

${ }^{2} \mathrm{EQ}$ merupakanKemampuan mengenal emosi diri yaitu kemampuan menyadari perasaan sendiri pada saat perasaan itu muncul sehingga mampu memahami dirinya, dan mengendalikan dirinya, dan mampu membuat keputusan yang bijaksana sehingga tidak 'diperbudak' oleh emosinya. Kemampuan mengelola emosi adalah kemampuan menyelaraskan perasaan (emosi) dengan lingkungannnya sehingga dapat memelihara harmoni kehidupan individunya dengan lingkungannya/orang lain. Kemampuan memotivasi diri merupakan kemampuan mendorong dan mengarahkan segala daya upaya dirinya bagi pencapaian tujuan, keinginan dan cita-citanya. Peran memotivasi diri yang terdiri atas antusiasme dan keyakinan pada diri seseorang akan sangat produktif dan efektif dalam segala aktifitasnya Kemampuan mengembangkan hubungan adalah kemampuan mengelola emosi orang lain atau emosi diri yang timbul akibat rangsangan dari luar dirinya. Kemampuan ini akan membantu individu dalam menjalin hubungan dengan orang lain secara memuaskan dan mampu berfikir secara rasional (IQ) serta mampu keluar dari tekanan (stress). Lihat Goleman, Kecerdasan ..., h. 21 
Dewasa ini banyak sekali kasus kenakalan remaja dan pelajar, di antaranya: tawuran, bunuh diri karena tidak lulus ujian nasional, depresi akibat diputus oleh pacar, perilaku seks bebas, pencurian, penodongan, penggunaan obat-obatan terlarang dan tindakan criminal lainnya. Kasus bunuh diri yang pernah terjadi dikalangan pelajar yaitu: Seorang pelajar nyaris bunuh diri karena ejekan sebutan anak tukang jual bubur ayam, Nanet yang berusia 12 tahun bunuh diri setelah dimarahi ibunya, Nop dalam usia 14 tahun ditemukan tergantung pada tiang di dalam gudang penyimpanan alat-alat rumah tangga. ${ }^{3}$ Yudianto berusia 12 tahun karena kecewa setelah dimarahi ibunya, Haryanto dalam usia 12 tahun melakukan percobaan bunuh diri hanya karena masalah uang $\mathrm{Rp}$ 1.500-,Tosan yang berusia 11 tahun ditemukan sudah tidak bernyawa diduga karena kehilangan layang-layang dan benangnya, dan FR, pelajar SMA Negeri 70 pekan lalu melakukan bunuh diri di dalam kamar mandi di kediaman orang tuanya di kawasan Semabung. ${ }^{4}$

Masa remaja merupakan masa yang memiliki suatu kebebasan dalam bergaul, hal tersebut tidak dapat dipungkiri bersama. Masalah kenakalan remaja dianggap masalah urgen. Hal yang sangat menarik kita bahas, dimana pada masa ini para remaja memiliki kebebasan dalam bertindak tanpa menghiraukan nasihat ataupun ucapan orang lain, mereka pada umumnya lebih mementingkan ego daripada kebersamaan.

Masa remaja dikenal sebagai masa penuh kesukaran. Bukan saja kesukaran bagi individu yang bersangkutan, tetapi juga bagi orang tuanya, masyarakat, bahkan seringkali bagi penegak hukum. Hal ini disebabkan masa remaja merupakan masa transisi antara masa kanak-kanak dan masa dewasa. Berdasarkan realitas di atas, ada banyak perilaku menyimpang yang dilakukan oleh para remaja khususnya yang masih menginjak jenjang pendidikan

\footnotetext{
${ }^{3}$ Bangka Pos,07 Agustus 2009.

${ }^{4}$ Bangka pos,28 September 2012.
} 
sekolah menengah atas yang mudah kita temui dalam kehidupan sehari-hari, perilaku tersebut antara lain: Suka bolos di jam sekolah, mengganggu aktivitas belajar berlangsung, melakukan kriminal, tawuran antar sekolah dan antara golongan (geng). Perilaku remaja tersebut merupakan perilaku yang menyimpang terhadap norma-norma yang berlaku di masyarakat. Semua fenomena kenakalan remaja tersebut bisa diminimalisir lewat kurikulum Pendidikan Islam yang direlevansikan dengan kecerdasan emosional, kurikulum merupakan komponen yang sangat penting dalam sistem pendidikan. Memperhatikan kurikulum dengan melihat kecerdasan emosional siswa sangat penting dalam proses pendidikan.

Kurikulum selalu mengalami perubahan atau lebih tepatnya penyempurnaan. hal ini dilakukan agar kurikulum sejalan dengan perkembangan prilaku remaja yang selalu mengikuti kemajuan zaman dan kurang cerdas dalam memilah arus globalisasi. Idealnya, kurikulum dapat memberikan jalan atau arahan terhadap permasalahan remaja sehingga di sekolah mereka lebih nyaman dan tenang sehingga permasahalan dapat dipecahkan karena sibuk dengan aktivitas di sekolah.

Penyebab yang melatarbelakangi kasus-kasus bunuh diri dan kenakalan remaja yang masih menginjak jenjak pendidikan sekolah menengah atas ini bukan masalah-masalah berat bahkan kadang terkesan sepele bagi orang yang berpikir rasional. Perilaku menyimpang tersebut, seperti berbagai kasus bunuh diri dan kenakalan siswa sekolah menengah atas, merupakan salah satu indikasi ketidak siapan anak menyikapi kondisi lingkungan sekitarnya. Rasa kecewa, malu, amarah, dan perasaan-perasaan negatif lain yang bersifat destruktif bersumber pada ketidakmampuan anak mengenali dan mengelola emosi, serta memotivasi diri. Kondisi seperti ini merupakan cerminan kecerdasan emosi yang rendah. 
Menurut M. Ustman Najati yang diterjemahkan oleh Irfan Salim, kecerdasan emosional adalah: Sebuah kecerdasan yang bisa memotivasi kondisi psikologis menjadi pribadi-pribadi yang matang. Kecerdasan emosional terwujud dalam bentuk kemampuan merasakan, memahami, dan secara efektif menerapkan daya dan kepekakan emosi sebagai sumber energi informasi, koneksi dan pengaruh manusia. Kecerdasan emosional seperti bahan bakar yang menyulut kreatifitas, kolaborasi, inisiatif, dan transformasi ${ }^{5}$.

Faktor emosi manusia ini cukup menarik untuk dijadikan pembahasan karena menyangkut realita kehidupan manusia yang tak seorang pun yang dapat menolak bahwa ia pernah sedih, takut, kecewa, bahagia, benci atau perasaan lain karena suatu peristiwa tertentu yang dialaminya, atau menyaksikan ekspresi orang lain dalam hal yang sama. Di sisi lain, aspek emosional dalam kehidupan individu terkait erat dengan aspek psikologis lainnya. Emosi dapat diibaratkan sebagai poros kehidupan manusia, yang jika terganggu aspek emosinya maka terganggu aspek kehidupan lainnya.

Emosi dapat menentukan kualitas hidup kita. Hal itu terjadi dalam setiap hubungan kita lakukan dalam persahabatan, dalam anggota keluarga masyarakat dan sebagainya. Pada saat ini, pesatnya ilmu pengetahuan dan kemajuan teknologi tidak selalu membawa kebaikan bagi manusia. Kehidupan yang semakin kompleks dengan tingkat stress yang semakin tinggi mengakibatkan individu semakin rentan mengalami berbagai gangguan baik fisik maupun psikis, gangguan psikis seperti kecemasan, stress, frustasi, agresivitas, perilaku anarkis, dan gangguan emosi lain semakin meningkat. Maka dari itu kecerdasan emosional dan pengembangan kurikulum sama pentingnya dalam proses pendidikan. Konsep-konsep dan praktek

${ }^{5}$ M. Utsman Najati, Belajar EQ dan SQ dari Sunnah,(terj) Irfan Salim, (Cet. VII; Jakarta: Hikmah, 2004), h. iv 
pendidikan yang berlangsung saat ini masih cenderung mengedepankan kecerdasan intelektual.

\section{BIOGRAFI GOLEMAN DAN AKTIVITAS INTELEKTUALNYA}

Goleman lahir di Stockton California, tinggal di Berkshires Massachasetts bersama istrinya Tara Bennet Goleman seorang ahli psikoterapi. Setelah menamatkan sekolah lanjutan tingkat atas, ia melanjutkan pendidikannya di universitas Amherst, dimana ia mendapat gelar sarjana Alfred Sloan dan lulus dengan predikat cumlaude. Setelah itu ia melanjutkan pada program S2 dan S3 nya di Harvard, dimana ia menjadi seorang anggota "ford" dan mendapat gelar MA dan Ph.D untuk mengembangkan klinik Psikologi dan Personaliti. ${ }^{6}$

Goleman termasuk salah seorang pendiri pembelajaran collaborative untuk kampus-kampus. Pembelajaran sosial dan emosi di Universitas Yale pusat studi anak (sekarang di Universitas Illionis Chicago), dengan misi membantu sekolahsekolah untuk memperkenalkan pelajaran-pelajaran literasi emosi. Program pembelajaran colaborative telah banyak dipraktekkan pada sekolah-sekolah di seluruh. Di samping itu Goleman merupakan mantan ketua perkumpulan penelitian mengenai kecerdasan emosi dalam organisasi. Pada tahun 2003, ia menerbitkan Destruction Emotions (emosi-emosi yang merusak), yaitu sejumlah dialog ilmiah antara kelompok psikolog, ahli saraf dan para filosof. Ia adalah anggota dewan komisaris institut "mind and life" yang mensponsori serial yang sedang berlangsung dalam dialog-dialog tersebut dan membuat penelitian yang relevan.

Selain itu juga aktif sebagai pengajar kelompok-kelompok peserta bisnis, kaum professional dan juga mengajar di kampuskampus Universitas. Ia telah menulis banyak pengetahuan mengenai kecerdasan dan perilaku di majalah "The New York

${ }^{6}$ Goleman, Kecerdasan Emosi..., h. xiii 
Times" selama bertahun-tahun. Awalnya, Goleman adalah seorang anggota pengunjung kepustakaan di Harvard dan ia juga seorang jurnalistik yang bekerja sebagai wartawan di surat kabar "The NewYork Times".

Selama kurang lebih sepuluh tahun, Goleman menulis artikel tentang ilmu-ilmu otak dan perilaku pada The New York Times. Ia pernah mengajar di Harvard (tempat ia meraih gelar doktornya) dan juga pernah menjadi editor senior di psychology Today. Untuk itu, ia telah menerima banyak penghargaan jurnalistik untuk karya karyanya tersebut, termasuk dua nominasi penghargaan yaitu "Prizer" untuk artikel-artikelnya di majalah Times dan sebuah penghargaan "Career Achieve Ment" (prestasi karir) untuk jurnalistik dari asosiasi psikologi Amerika.

Selain Emotional Intelligence, buku-bukunya yang telah diterbitkan adalah Vital Lies, Simple Truths, The Meditative Mind, Working With Emotional Intelligence dan menjadi penulis pendamping buku The Creative 17 Spirit. Dan buku terbarunya adalah Primal Leadership Realizing The Power Of Emotional Intelligence.

\section{KONSEP KECERDASAN EMOSIONAL DANIEL GOLEMAN DAN KURIKULUM PAI}

Daniel Goleman dalam memperkenalkan konsep kecerdasan emosi dapat dilihat dalam buku "Emotional intelligence":

"emotional intelligence: abilities such as being able to motivate oneself and persist in the face of frustrations, to control impulse and delay gratification, to regulate one's moods and keep distress from swamping the ability to think, to empathize and to hope"?

Dari konsep tersebut diketahui bahwa kecerdasan emosi adalah kemampuan-kemampuan seperti kemampuan memotivasi diri sendiri dan bertahan dalam menghadapi frustasi, mengendalikan dorongan hati dan tidak berlebihan, mengatur

${ }^{7}$ Goleman, Kecerdasan Emosi..., h. 35 
suasana hati dan menjaga agar tetap berfikir jernih, berempati dan berdoa.

Menurut konsep Daniel Goleman yang menjadi titik tekan dalam pandangannya adalah merujuk pada kecerdasan diri dan kecerdasan sosial. Pendapat Goleman ini serupa dengan dua kecerdasan yang tercantum dalam multiple intelligence yang dikembangkan oleh Howar Gardner lewat projectspectrum, yakni interpersonal intelligence dan intrapersonal intelligence.

Konsep kecerdasan manusia pada mulanya lahir akibat adanya berbagai tes mental yang dilakukan oleh berbagai psikolog untuk menilai manusia ke dalam berbagai tingkat kecerdasan (Intelligence Quotient). Tes IQ adalah cara yang digunakan untuk menyatakan tinggi rendahnya angka yang dapat menjadi petunjuk mengenai kedudukan tingkat kecerdasan seseorang. Menurut teori ini, semakin tinggi IQ seseorang maka semakin tinggi pula kecerdasannya. ${ }^{8}$

Seiring dengan perkembangannya, tes inteligensi yang muncul pada awal abad ke-20 yang dipelopori oleh Alferd Binet ${ }^{9}$ ternyata tes inteligensi memiliki kekurangan atau kelemahan. Kekurangan itulah yang melatarbelakangi munculnya teori baru dan sebagai alat untuk menyerang teori tersebut.Teori baru ini dipopulerkan oleh Daniel Goleman yang dikenal dengan istilah Kecerdasan Emosi (Emotional Intelligence).Menurut Daniel Goleman, EQ sama ampuhnya dengan IQ, dan bahkan lebih. ${ }^{10}$ Terlebih dengan adanya hasil riset terbaru yang menyatakan bahwa kecerdasan kognitif (IQ) bukanlah ukuran

${ }^{8}$ Sukamto,Sejarah Perkembangan Tes Inteligensi Suatu Sarana Pengungkap Psikologis, (Yogyakarta: Lembaga Penelitian Universitas Cokroaminoto, 1984), h. 15

${ }^{9}$ Saifuddin Azwar, Pengantar Psikologi Inteligensi, (Yogyakarta: Pustaka Pelajar, 1966), h. 51 2000 .

${ }^{10}$ Lihat Sukidi, “Kecerdasan Spiritual” Harian Kompas, 15 Desember, 
kecerdasan (Intelligence) yang sebenarnya, ternyata emosilah parameter yang paling menentukan dalam kehidupan manusia.

Menurut Daniel Goleman, IQ hanya mengembangkan 20\% terhadap kemungkinan kesuksesan hidup, sementara 80\% lainnya diisi oleh kekuatan-kekuatan lain. ${ }^{11}$ Ungkapan Goleman ini seolah menjadi jawaban bagi situasi 'aneh' yang sering terjadi di tengah masyarakat, di mana ada orang-orang yang diketahui ber-IQ tinggi ternyata tidak mampu mencapai prestasi yang lebih baik dari yang ber-IQ lebih rendah.

Kelebihan lain dari kecerdasan emosi ini adalah kenyataan bahwa kecerdasan emosi bukanlah kecerdasan statis yang diperoleh karena 'warisan' orang tua seperti IQ. Selama ini telah diketahui bahwa seseorang yang terlahir dengan IQ rendah tidak dapat direkayasa untuk menjadi seorang jenius. Begitu pula sebaliknya, seseorang yang dilahirkan dari orang tua ber-IQ tinggi kemungkinan besar akan 'mengikuti jejak' orang tuanya dengan ber-IQ tinggi juga. Adapun kecerdasan emosi dapat tumbuh dan berkembang seumur hidup dengan belajar. Cerdas dan tidaknya emosi seseorang tergantung pada proses pembelajaran, pengasahan, dan pelatihan yang dilakukan sepanjang hayat. ${ }^{12}$

Emosi sangat mempengaruhi kehidupan manusia ketika dalam mengambil keputusan, tidak jarang suatu keputusan diambil melalui emosinya. Jarang keputusan yang diambil manusia murni dari pemikiran rasionalnya, karena seluruh keputusan manusia memiliki warna emosional. Jika seseorang memperhatikan keputusan-keputusan dalam kehidupan manusia, ternyata keputusannya lebih banyak ditentukan oleh emosi dari pada akal sehat.

\footnotetext{
${ }^{11}$ Maurice J. Elias, dkk.,Cara-Cara Efektif Mengasuh Anak dengan EQ, (Bandung: Kaifa, 2000), h. 11

${ }^{12}$ Majalah Ummi, “Anak Cerdas Dunia Akhirat", Edisi Spesial No. 4 th 2002, h. 19
} 
Emosi yang begitu penting itu sudah lama ditinggalkan oleh para peneliti. Karena itulah Goleman mengusulkan selain memperhatikan kecerdasan otak, manusia juga harus memperhatikan kecerdasan emosi. ${ }^{13}$ Manusia secara alamiah merindukan kehidupan yang tenang dan sehat baik jasmani maupun rohani.Suatu kenyataan menunjukkan bahwa peradaban manusia yang semakin maju berakibat pada semakin kompleksnya gaya hidup manusia.

Kebahagian manusia tidak tergantung pada fisik melainkan pada faktor pertumbuhan emosinya, karena emosi sebagai tenaga-tenaga penggerak dalam hidup, yang menyebabkan manusia berkembang maju, dan mundur ke belakang. ${ }^{14}$ Tidak seorang pun yang tidak menginginkan ketenangan dan kebahagiaan dalam hidupnya, setiap orang akan berusaha mencarinya, meskipun tidak semua dapat mencapai yang diinginkannya itu. berbagai sebab dan rintangan yang mungkin terjadi sehingga banyak orang yang mengalami kegelisahan, kecemasan, ketidakpuasan dan emosi yang berlebihan.

Dengan kata lain, semakin maju orang atau masyarakat, semakin banyak pula komplikasi hidup yang dialaminya. Persaingan, perlombaan, dan pertentangan akibat kebutuhan dan keinginan yang harus tetap dipenuhi. Kecerdasan emosi tidak banyak tergantung oleh faktor-faktor luar seperti keadaan sosial, ekonomi, politik, akan tetapi lebih tergantung pada cara dan sikap dalam menghadapi faktor-faktor tersebut. Adapun yang menentukan ketenangan dan kebahagiaan hidup di antaranya adalah kecerdasan emosi, yaitu cara seseorang menanggapi suatu persoalan dan kemampuannya untuk menyesuaikan diri. kecerdasan emosi pula yang menentukan orang mempunyai kegairahan hidup atau bersikap pasif.

\footnotetext{
${ }^{13}$ Ahmad Mubarok, Solusi Krisis Kerohanian Manusia Modern, (Jakarta: Paramadina, 2000), h. 13-14

${ }^{14}$ Jalaluddin Rakhmat, Meraih Cinta Ilahi Pencerahan Sufistik, (Bandung: Rosdakarya, 2001), h. 234
} 
Orang yang sehat mentalnya tidak mudah putus asa, pesimis, dan apatis karena dia dapat menghadapi semua rintangan atau kegagalan dalam hidup dengan tenang dan wajar, serta menerima kegagalan itu sebagai suatu pelajaran yang akan membawa kepada kesuksesan. Begitu pula yang diungkapkan Daniel Goleman bahwa kerugian pribadi akibat rendahnya kecerdasan emosional dapat berkisar mulai dari kesulitan perkawinan, pendidikan anak, buruknya kesehatan jasmani, hambatan perkembangan intelektual, hingga ketidaksuksesan karir. ${ }^{15}$ Karena adanya fenomena diatas, dan kehidupan masyarakat di sekitar, bahwa kehidupan manusia tidak lepas dari konflik-konflik maupun problem-problem yang tidak jarang manusia mengalami ketegangan-ketegangan, pesimis, frustasi, dan stres. Dalam keadaan demikian, sebagaian orang lantas menyelesaikannya dengan cara emosional, dan sering kali sembrono, serampangan, lantah dan menyimpulkan atau melontarkan pernyataan yang sebenarnya belum final pengkajiannya pada waktu sedang emosi. Ini semua dilakukan karena belum adanya kecerdasan emosi, dan menjadikan mental tidak sehat.

Padahal dari generasi ke generasi manusia semakin cerdas akan tetapi ketrampilan emosional dan sosialnya merosot tajam. Hal ini pula yang melemahkan kecerdasan emosi.Akibatnya, muncul patologi sosial yang ada dalam berbagai bentuk penyakit kejiwaan.Seperti krisis kepercayaan, ketidakjujuran, kebosanan, dan kejenuhan hidup sehingga munculnya penyakit-penyakit kejiwaan yang berdampak negatif pula pada tata kehidupan pribadi dan sosial yang mengakibatkan ketidaksehatan mental atau tidak adanya kesehatan mental.

Pada persoalan ini, maka sangat krusial konsep Daniel Goleman diangkat sebagai solusi karena pada dasarnya konsepkonsep Daniel Goleman mencoba melihat aspek manusia

\footnotetext{
${ }^{15}$ Goleman, Kecerdasan Emosi..., h. 37
} 
khususnya pada perasaan atau emosi manusia. Dan konsepkonsep yang ditawarkan Daniel Goleman akan mengantarkan manusia untuk memperoleh perasaan dapat mempengaruhi seseorang, jadi perasaan yang ditempatkan pada tempatnya akan mengontrol luapan-luapan emosi. konsepDaniel Goleman merupakan konsep yang cocok diterapkan pada zaman sekarang ini.

Dalam perspektif Islam, segala macam emosi dan eksprisinya, diciptakan oleh Allah melalui ketentuannya, emosi diciptakan oleh Allah untuk membentuk manusia yang lebih sempurna. ${ }^{16}$ Banyak ayat Alquran dan Hadis menggambarkan emosi dengan muatan yang berbeda, seperti pada surat (Q.S AlNajm: 43-44), yaitu emosi positif dan emosi negatif. Kedua jenis muatan emosi yang berlawanan ini bahkan sering dipasangkan untuk menimbulkan efek kontradiktif yang menguatkan makna kalimat dalam al-Qur'an antara lain diceritakan dalam Q.S Ali Imron(3): 106.

Alquran juga banyak menggambarkan bahwa satu kualitas emosi memiliki tingkatan intensitas tertentu.Satu peristiwa yang sama dapat membuat banyak orang mengeluarkan respons emosional yang berbeda-beda intensitasnya. perasaan senang, misalnya dapat muncul dalam respons tersenyum tertawa, atau respons lain yang lebih.

Dalam memberikan petunjuk pada manusia, Alquran dan Hadits banyak membahas tentang berbagai jenis ekspresi emosional manusia ketika menghadapi atau mengalami sesuatu, eksperesi yang ditampilan sangat kaya, termasuk emosi primer dan emosi sekunder.

${ }^{16}$ Aliah B. Purwakania Hasan, Psikologi Perkembangan Islam, (Jakarta: Rajawali Press, 2006), h. 161 


\section{KURIKULUM PENDIDIKAN AGAMA ISLAM}

Kurikulum Pendidikan Agama Islam di madrasah maupun di sekolah umum pada dasarnya sama, meliputi: Hubungan manusia dengan Allah swt., hubungan manusia dengan dirinya sendiri, hubungan manusia dengan sesama manusia, hubungan manusia dengan makhluk lain dan lingkungan alam sekitar. Dalam kurikulum Pendidikan Agama, paling tidak terdapat memuat pokok bahasan tentang: Sejarah Kebudayaan Islam, Aqidah Akhlak, Fiqh dan Alquran-Hadis.

\section{Sejarah Kebudayaan Islam (SKI)}

Materi Sejarah Kebudayaan Islam meliputi: masuknya Islam ke Indonesia, jalur-jalur masuknya Islam di Indonesia, perkembangan Islam di Indonesia, perkembangan ilmu pengetahuan dan kebudayaan, peranan umat Islam dalam mengusir penjajah, hikmah sejarah perkembangan Islam di Indonesia, perilaku penghayatan sejarah perkembangan Islam di Indonesia.

Jadi, materi yang ada di pelajaran Sejarah Kebudayaan Islam tersebut kalau disisipkan dengan kecerdasan emosional maka akan menghasilkan kualitas individu yang aktif, tidak egois, cerdas dalam mengambil hikmah, akan berprilaku adil dengan memahami sejarah-sejarah besar umat Islam.

\section{Aqidah Akhlak}

Pelajaran Aqidah Akhlak mengajarkan dan membimbing siswa untuk mengetahui, memahami dan meyakini akidah Islam serta dapat membentuk dan mengamalkan tingkah laku yang baik yang sesuai dengan ajaran Islam. ${ }^{17}$ Materi Aqidah Akhlak meliputi iman kepada Allah SWT, iman kepada hari akhir, pengertian iman, penggolongan hari akhir, fase-fase menuju kehidupan

${ }^{17}$ Depag RI, Standar Kompetensi Madrasah, (Jakarta, Dirjen Binbaga Islam,2004), h. 22 
akhirat, iman kepada qada' dan qadar, hubungan qada' dan qadar, dalil-dalil yang berkenaan dengan qada' dan qadar.

Jadi, dalam pelaksanaan mata pelajaran Akidah Akhlak harus ada kurikulum yang memuat emosional agar dapat memberikan seseorang untuk memahami, meyakini dan menghayati kebenaran ajaran Islam serta bersedia mengamalkannya dalam kehidupan sehari-hari. Mengajarkan dan mengarahkan tentang tata dalam berhubungan, baik dengan Tuhannya ataupun dengan sesamanya sesuai dengan kaidahkaidah Islam. Supaya bisa mendorong peserta didik untuk mengembangkan pemahaman dan keyakinan tentang adanya Allah sebagai sumber kehidupan. Perbaikan kesalahan-kesalahan, kelemahan-kelemahan peserta didik dalam keyakinan, pengamalan ajaran agama Islam dalam kehidupan sehari-hari dengan harapan bisa meminimalisir prilaku peserta didik dari hal-hal negatif dari lingkungannya ataupun dari budaya asing yang akan dihadapinya.

\section{Fiqh}

Materi Fiqh di SMA meliputi : rukun waris, macam-macam waris, perhitungan waris, pernikahan, rukun nikah, hukum nikah dan rujuk talak. Pelajaran fiqh tersebut bisa dipadukan dengan kecerdasan emosional agar dapat memberikan pengetahuan, mentaati hukum, terampil melaksanakan hukum, Mentaati hukum berarti siswa mau menerima dan mematuhi ketentuan hukum yang telah ditetapkan oleh Allah SWT.

\section{Alquran-Hadis}

Materi pelajaran Alquran hadis meliputi: macam-macam sunnah: sunnah qauliyah, Sunnah dan Sunnah taqririyah, dalildalil yang berkenaan dengan toleransi, membiasakan perilaku toleransi, dalil-dalil yang berkenaan dengan larangan ghibah, fitnah israf dan tabzir. 
Pendekatan emosional dalam materi ini dimaksudkan sebagai suatu usaha untuk menggugah perasaan dan emosi siswa dalam meyakini, memahami dan menghayati ajaran agamanya. Untuk mencapai tujuan pendekatan emosional ini, metode yang perlu dipertimbangkan adalah metode ceramah, bercerita dan sosio drama.

Pendekatan emosional adalah pendekatan dalam pendidikan yang dilakukan guru terhadap muridmelalui rangsangan verbal maupun non verbal serta melalui sentuhansentuhan emosi (perasaan). Misalnya melalui rangsangan verbal seperti ceramah, cerita, sindiran, pujian, ejekan, berita, dialog, anjuran, perintah dan sebagainya.Sedangkan rangsangan nonverbal seperti bentuk perilaku berupa sikap dan perbuatan.

\section{INTEGRASI KECERDASAN EMOSIONAL DALAM KURIKULUM PENDIDIKAN AGAMA ISLAM}

Tidak semua materi dalam kurikulum Pendidikan Agama Islam dapat direlevansikan secara detail dengan kecerdasan emosional dalam perspektif Daniel Goleman, karena dengan alasan inilah materi-materi dalam kurikulum Pendidikan Agama Islam yang akan dibahas disini meliputi hubungan manusia dengan Allah swt., hubungan manusia dengan dirinya sendiri, hubungan manusia dengan sesama manusia, hubungan manusia dengan makhluk lain dan lingkungan alam sekitar.

Kecerdasan emosional salah satunya adalah kesadaran emosional $^{18}$ yaitu melatih kita untuk merasakan sensasi emosi pada diri sendiri. Membangun otot emosional merupakan program pelatihan yang dirancang berdasarkan fakta bahwa cara kerja kebugaran emosional sama dengan kebugaran fisik.

Dalam hal ini, bisa kita ambil hikmah dalam pelajaran kisahkisah tarikh kebudayaan islam seperti kisah Seorang lelaki Arab

${ }^{18}$ Jeane Segal, Melejitkan Kepekaan Emosional, (Bandung: Mizan Media Utama, 2000), h. 69-89. 
bernama Tsumamah bin Itsal dari Kabilah Al Yamamah pergi ke Madinah dengan tujuan hendak membunuh Nabi Saw., segala persiapan telah matang, persenjataan sudah disandangnya, dan ia pun sudah masuk ke kota suci tempat Rasulullah tinggal. Dengan semangat meluap-luap ia mencari majlis Rasulullah, langsung mendatanginya untuk melaksanakan maksud tujuannya. Tatkala Tsumamah datang, Umar bin Khattab ra. yang melihat gelagat buruk pada penampilannya langsung menghadang. Umar bertanya, "Apa tujuan kedatanganmu ke Madinah? Bukankah engkau seorang musyrik?” Dengan terang-terangan Tsumamah menjawab, "Aku datang ke negeri ini hanya untuk membunuh Muhammad".

Mendengar ucapannya, dengan sigap Umar langsung menyergapnya. Tsumamah tak sanggup melawan Umar yang perkasa. Umar berhasil merampas senjatanya dan mengikat tangannya kemudian membawanya ke masjid. Setelah mengikat Tsumamah di salah satu tiang masjid Umar segera melaporkan kejadian ini pada Rasulullah. Rasulullah segera keluar menemui orang yang bermaksud membunuhnya itu. Setibanya di tempat, beliau mengamati wajah Tsumamah baik-baik, kemudian berkata pada para sahabatnya, "Apakah ada di antara kalian yang sudah memberinya makan?”.

Para sahabat Rasul yang ada di tempat itu terperanjat kaget dengan pertanyaan Nabi Saw. Umar yang sejak tadi menunggu perintah Rasulullah untuk membunuh orang ini seakan tidak percaya dengan apa yang didengarnya dari Rasulullah. Maka Umar memberanikan diri bertanya, "Makanan apa yang anda maksud wahai Rasulullah? Orang ini datang ke sini ingin membunuh bukan ingin masuk Islam!.” Namun Rasulullah tidak menghiraukan sanggahan Umar. Beliau berkata, “Tolong ambilkan segelas susu dari rumahku, dan buka tali pengikat orang itu". 
Walaupun merasa heran, Umar mematuhi perintah Rasulullah. Setelah memberi minum kepada Tsumamah, Rasulullah dengan sopan berkata kepadanya, "Ucapkanlah Laa ilaha illa-Lallah (Tiada ilah selain Allah)." Si musyrik itu menjawab dengan ketus, "Aku tidak akan mengucapkannya!". Rasulullah membujuk lagi, "Katakanlah, Aku bersaksi tiada ilah selain Allah dan Muhammad itu Rasul Allah." Namun Tsumamah tetap berkata dengan nada keras, "Aku tidak akan mengucapkannya!" Para sahabat Rasul yang turut menyaksikan tentu saja menjadi geram terhadap orang yang tak tahu diuntung itu. Tetapi Rasulullah malah membebaskan dan menyuruhnya pergi.

Tetapi belum berapa jauh dari masjid, dia kembali kepada Rasulullah dengan wajah ramah berseri. Ia berkata, "Ya Rasulullah, aku bersaksi tiada ilah selain Allah dan Muahammad Rasul Allah." Rasulullah tersenyum dan bertanya, "Mengapa engkau tidak mengucapkannya ketika aku memerintahkan kepadamu?" Tsumamah menjawab, “Aku tidak mengucapkannya ketika masih belum kau bebaskan karena khawatir ada yang menganggap aku masuk Islam karena takut kepadamu, namun setelah engkau bebaskan, aku masuk Islam semata-mata karena mengharap keridhaan Allah Robbul alamin."

Pada suatu kesempatan, Tsumamah bin Itsal berkata, "Ketika aku memasuki kota Madinah, tiada yang lebih kubenci dari Muhammad. Tetapi setelah aku meninggalkan kota itu, tiada seorang pun di muka bumi yang lebih kucintai selain Muhammad Rasulullah." Apakah kita pengikut ajaran beliau? Tetapi sejauh mana kita bisa memaafkan kesalahan orang? Seberapa besar kita mencintai sesama? kalau tidak, kita perlu menanyakan kembali ikrar kita yang pernah kita ucapkan sebagai tanda kita pengikut beliau. Sungguh, beliau adalah contoh yang sempurna sebagai seorang manusia biasa. Beliau adalah Nabi, suami, bapak, pimpinan, teman dan tetangga yang sempurna. Maka benar jika Allah mengatakan bahwa Beliau adalah teladan yang sempurna. 
Penanaman kecerdasan emosional dapat diintegrasikan dalam materi pelajaran sejarah seperti yang dipaparkan di atas. Demikian halnya pada mata pelajaran lain, seperti Fiqh. Dalam Fiqh, diajarkan, misalnya, tentang kewajiban zakat dengan segala aturan-aturan yang terkait dengannya. Pendekatan yang lazim digunakan tentu saja pendekatan hukum. Pendekatan hukum ini akan lebih efektif jika diintegrasikan dengan penanaman sikap empati yang merupakan salah satu bagian dari kecerdasan emosional.

Empati (mengetahui perasaan orang lain) datang dengan sendirinya dan mengalir dari kesadaran aktif. ${ }^{19}$ Dalam emotional intelegence, Daniel Goleman menyebut empati ini sebagai keterampilan dasar manusia. Orang yang memiliki empati adalah pemimpin alamiah yang dapat mengekspresikan dan mengartikulasikan sentimen kolektif yang tidak terucapkan untuk membimbing satu kelompok menuju cita-citanya.

Seseorang yang memiliki kecerdasan emoisonal tinggi dapat bekerja efektif dengan siapapun karena dia mendengarkan tanpa prasangka. Kesadaran tentang pentingnya perasaan orang lain dan perasaan sendiri memudahkan kita menghargai pendapat dan nilai-nilai orang lain yang berbeda, tanpa merasa terancam oleh perbedaan tersebut. Kecerdasan emosional yang memadai, akan dapat berkinerja dan mempunyai produktivitas yang tinggi. Guru menyampaikan permasalahan kehidupan yang berkaitan dengan kepemilikan uang dan keharusan Islam untuk membayar zakat, infak dan sedekah. Dengan diskusi kelas siswa mengidentifikasi pengertian zakat, infak dan sedekah serta perbedaan prinsipil antara ketiganya.

Siswa diminta menunjukkan dan membaca/menghafal dalil naqli tentang zakat, infak dan sedekah. Guru memberikan tugas kepada siswa untuk menghitung besarnya zakat mal yang harus dibayarkan dengan memberikan soal ceritera yang berkaitan

${ }^{19}$ Ibid., h. 137-160. 
dengan pembayaran zakat: seperti: Pak Amin memiliki deposito sebesar Rp. 35 juta dan sudah dimiliki selama 18 bulan. Apakah Pak Amin sudah termasuk wajib Zakat? Mengapa? Kalau sudah berapa zakat yang harus dibayarkan?

Setelah anak memahami pengertian zakat, infak, sedekah, dan penghitungan zakat: dengan teknik rangking anak diminta membuat prioritas terhadap sebuah masalah: Jika kamu mendapatkan uang sebesar dua juta rupiah, prioritas apa yang akan kamu lakukan dengan uang tersebut: ditabung, mentraktir makan teman, memberikan sebagian anak miskin dan yatim, membayar uang sekolah. Untuk merangking dapat dilakukan secara individual maupun diskusi kelompok.

Bila siswa memilih satu jawaban, guru dapat mendiskusikan lebih jauh dengan siswa, mengapa dia memilih jawaban tersebut. Setelah selesai diskusi dan tanya jawab, guru mengalokasikan waktu kurang lebih sepuluh menit untuk siswa dapat membuat kesimpulan dan refleksi dari pembelajaran yang diterima dengan bimbingan dari guru. Guru membagi siswa dalam kelompok, menugaskan anak untuk: menyisihkan sebagaian uang jajan dalam satu minggu kemudian uang dikumpulkan, secara berkelompok anak meyedekahkan uangnya kepada anak-anak miskin dan anak jalanan sambil berbincang dengan mereka di sekitar sekolah.

Siswa menyusun laporan dan sharing pengalaman dengan kelompok yang lain dalam satu kelas. Pembelajaran pendidikan Agama Islam pada aspek kognitif tetap dilaksanakan, akan tetapi aspek sikap perlu lebih ditekankan. Selama ini ada kesan bahwa ibadah mahdlah lebih tinggi nilainya dibandingkan dengan muamalah maupun akhlaq. Dengan kesan demikian kecenderungan menganggap bahwa jika sudah mengerjakan shalat, puasa, zakat dan haji, lalu memandang kurang penting implementasi nilai-nilai ibadah tersebut dalam konteks muamalah dan akhlaq. 
Kecenderungan ini berimplikasi pada seseorang yang taat mengerjakan shalat tetapi tidak peduli dan tidak tenggang rasa dengan orang lain (kurang memiliki sikap empati). Atau pada orang-orang yang mengatasnamakan ajaran Islam justru bertindak emosional, saling menuduh dan bertindak brutal mengesampingkan nilai-nilai akhlaq Islami yang mengajarkan kecerdasan Emosional. Pembelajaran pendidikan agama Islam jangan hanya bersifat teoritis, akan tetapi lebih ditekankan pada aplikasi perilaku dalam kehidupan sehari-hari. Pembelajaran tauhid tidak semata penjelasan tauhid dalam dimensi vertikal, tetapi pengembangan materi tauhid dalam dimensi horisontal/tauhid sosial akan lebih bermanfaat bagi upaya pengembangan kecerdasan emosional.

Mengkaitkan secara langsung materi pendidikan agama Islam pada masalah-masalah aktual yang dialami anak baik di rumah, di sekolah maupun di masyrakat lebih menunjang bagi kecerdasan emosi anak. Mengapa banyak anak jalanan? Mengapa ada perkelahian? Mengapa ada rumah anak yatim? Hal-hal tersebut dapat menjadi topik yang didiskusikan denga anak.

Problem solving yang dikemukakan oleh anak sesuai dengan usia mereka. Argumen anak dapat menggambarkan siapa dirinya (anak mengenal dirinya sendiri) serta memberikan kesadaran bagi mereka tentang pentingnya kebersamaan dan rasa bersyukur. Demikian juga langkah apa yang dilakukan oleh seorang anak untuk menggalang kebersamaan dengan temantemannya memberikan sikap empati anak.

\section{PENUTUP}

Kecerdaan emosional adalah kemampuan untuk mengenali perasaan, meraih dan membangkitkan perasaan untuk membantu pikiran, memahami perasaan dan maknanya, dan mengendalikan perasaan secara mendalam sehingga membantu perkembangan emosi dan intelektual. 
Istilah emosi ini kemudian diekspresikan dalam bentuk kesedihan, ketakutan, kebencian, kegalauan, dan kebahagiaan berdiri tegak pada aneka ragam emosi yang berkaitan. Kemarahan misalnya, bisa bervariasi dalam kekuatannya, yang berkisar dari rasa jengkel yang memunculkan kemarahan karena benci, kemarahan karena naik darah, dan kemarahan yang dingin. Variasi-variasi dalam intensitas dan masing-masing emosi jelas tampak pada ekspresi wajah.

Kurikulum PAI SMA yang disusun harus menunjukkan ciri dan spesifikasinya, baik dalam bentuk geografis maupun sosial budaya. Adanya relevansi kurikulum PAI di SMA terhadap kecerdasan emosional, sehingga tidak terjadi penumpukan pengangguran dari output lembaga pendidikan, yang disebabkan output lebih besar daripada kebutuhan. Penyusunan kurikulum PAI yang dilakukan oleh lembaga pendidikan harus melibatkan semua pihak baik guru, Komite, masyarakat, pengurus/yayasan, stake holder, pakar pendidikan, dan semua pihak yang kompeten di dunia pendidikan. Dalam penyusunan kurikulumnya harus mampu menggali potensi, minat, bakat, kemampuan, keberagaman serta perbedaan individu siswa yang mencakup ranah kognitif, afektif dan psikomotorik.

Relevansi kecerdasan emosional siswa SMA terhadap pendidikan agama Islam yaitu suatu jalan untuk meraih kesuksesan seorang siswa. Seorang siswa yang sukses atau berhasil tentunya memiliki emosi yang baik, mampu mengelola emosinya, dapat mengarahkan emosinya melalui pendidikan Islam.

Dengan demikian seseorang siswa yang sukses bukanlah seseorang yang melakukan kesia-siaan dengan mempelajari bakat baru, akan tetapi mereka yang lebih fokus menyesuaikan emosi yang dimiliki dengan tuntutan peran (sebagai siswa). Jadi kecocokan antara peran, bakat,kompetensi dan kecerdasan 
emosional adalah faktor penting dalam menentukan performa seorang siswa.

\section{DAFTAR PUSTAKA}

Bangka Pos, 07 Agustus 2009.

Bangka pos, 28 September 2012.

Casmini, “Arti Penting Kecerdasan Emosi dalam Dakwah", dalam Jurnal Dakwah, 11 Januari-Juni 2001.

Depag RI, Standar Kompetensi Madrasah, Jakarta, Dirjen Binbaga Islam,2004

Departemen Pendidikan Nasional, Kamus Besar Bahasa IndonesiaEdisi Ketiga, Jakarta: Balai Pustaka, 2005.

Goleman, Daniel, Kecerdasan Emosi Untuk Mencapai Puncak Prestasi, Cet. IV (terj) alex Tri Kantjono Widoo Jakarta: Gramedia Puskta Utama 2001.

Goleman, Daniel, Kecerdasan Emosi Untuk Mencapai Puncak Prestasi, Cet. IV (terj) alex Tri Kantjono Widoo Jakarta: Gramedia Puskta Utama 2001.

Jalaluddin Rakhmat, Meraih Cinta Ilahi Pencerahan Sufistik, Bandung: Rosdakarya, 2001.

Jeane Segal, Melejitkan Kepekaan Emosional, Bandung: Mizan Media Utama, 2000.

Lihat Sukidi, “Kecerdasan Spiritual " Harian Kompas, 15 Desember, 2000.

M. Utsman Najati, Belajar EQ dan SQ dari Sunnah,(terj) Irfan Salim, Jakarta: Hikmah, 2004. Majalah Ummi, "Anak Cerdas Dunia Akhirat", Edisi Spesial No. 4 th 2002.

Maurice J. Elias, dkk.,Cara-Cara Efektif Mengasuh Anak dengan $E Q$, Bandung: Kaifa, 2000. 
Mubarok, Ahmad, Solusi Krisis Kerohanian Manusia Modern, Jakarta: Paramadina, 2000.

Oemar Hamalik, Manajemen Pengembangan Kurikulum, Bandung:Remaja Rosdakarya, 2006.

Purwakania Aliah B. Hasan, Psikologi Perkembangan Islam, Jakarta: Rajawali Press, 2006.

Saifuddin Azwar, Pengantar Psikologi Inteligensi, Yogyakarta: Pustaka Pelajar1966.

Sukamto,Sejarah Perkembangan Tes Inteligensi Suatu Sarana Pengungkap Psikologis, Yogyakarta: Lembaga Penelitian Universitas Cokroaminoto, 1984. 
Vol. 12, No. 1, Juni 2015: 141-163 